TI 2014-093/VIII

Tinbergen Institute Discussion Paper

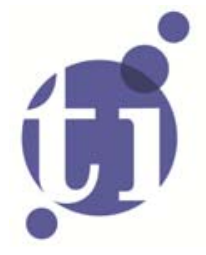

\title{
Location Choices of highly Educated Foreign Workers: \\ the Importance of Urban Amenities
}

\author{
Or Levkovich
}

Jan Rouwendal 
Tinbergen Institute is the graduate school and research institute in economics of Erasmus University Rotterdam, the University of Amsterdam and VU University Amsterdam.

More TI discussion papers can be downloaded at http://www.tinbergen.nl

Tinbergen Institute has two locations:

Tinbergen Institute Amsterdam

Gustav Mahlerplein 117

1082 MS Amsterdam

The Netherlands

Tel.: +31(0)205251600

Tinbergen Institute Rotterdam

Burg. Oudlaan 50

3062 PA Rotterdam

The Netherlands

Tel.: +31(0)10 4088900

Fax: $+31(0) 104089031$

Duisenberg school of finance is a collaboration of the Dutch financial sector and universities, with the ambition to support innovative research and offer top quality academic education in core areas of finance.

DSF research papers can be downloaded at: http://www.dsf.nl/

Duisenberg school of finance

Gustav Mahlerplein 117

1082 MS Amsterdam

The Netherlands

Tel.: +31(0)20 5258579 


\title{
Location choices of highly educated foreign workers: the importance of urban amenities
}

\author{
Or Levkovich ${ }^{\mathrm{a}}$ and Jan Rouwendal ${ }^{\mathrm{a}, \mathrm{b}}$ \\ a) Department of Spatial Economics, VU University, De Boelelaan 1105, 1081 HV Amsterdam. \\ b) Tinbergen Institute, Mahlerlaan , Amsterdam
}

This version: June $29^{\text {th }} 2014$

Key words: urban amenities, foreign workers

JEL codes: F68, R53, R11

\begin{abstract}
In the globalized economy the presence of migrants is essential for urban and regional growth, and it is therefore important to know what makes a city an attractive place for highly skilled migrants. This paper aims to shed light on this issue by considering the location choice of highlyeducated foreign workers, and if and how their valuation of urban amenities differs from domestic workers. To do so, we apply a residential location-choice model to estimate the attractiveness of residential locations in the Dutch Randstad for low and high-skilled, domestic and foreign workers, and calculate and compare their willingness to pay for each of these amenities.
\end{abstract}

Acknowledgement: We would like to thank Mark van Duijn and Jan Möhlmann for their useful comments and technical assistance with the estimation of the sorting model. 



\section{Introduction}

Skills are generally thought to be one of the drivers of economic growth. Human capital is an important determinant of productivity and 'the race between education and technology' (Goldin \& Katz, 2009) is an important driver of the income distribution. Globalization has resulted in a decline of manufacturing in the western world and a shift of the core activities towards innovative and skill-intensive industries, which require human capital as one of its key resources. The increasing mobility, particularly of highly educated workers, underlines the need to make cities attractive places to work and live for such people. The ability of cities to attract international migrants, particularly those with higher human capital levels is therefore increasingly seen as an important indicator of their growth potential (Edward Glaeser \& Resseger, 2010; EL Glaeser \& Saiz, 2003; Moretti, 2012).

The effect of immigration on economic growth has been studied extensively in the recent literature, including a in particular the examination of the effects of different compositions of groups of migrants, mostly based on skill and nationality diversification. Positive effects on

productivity may result from the diversity in ideas and skills, which may improve innovation (Hunt \& Gauthier-Loiselle, 2008; Niebuhr, 2010; Ottaviano \& Peri, 2006; Suedekum, Wolf, \& Blien, 2009). Also, immigration flows of human capital were found to encourage local employment levels through a multiplier effect (Moretti \& Thulin, 2013; Moretti, 2010). Moreover, the presence of migrants may positively affect the utility of residing in a region by creating a multicultural environment which is perceived positively by a tolerant native population (Moretti, 2004; Niebuhr, 2010; Ottaviano \& Peri, 2006; Suedekum et al., 2009). In contrast, negative impacts on productivity may arise from communication and cultural barriers, and a relatively high share of migrants may also crowd-out natives in jobs, particularly those with medium skill levels (Eeckhout, Pinheiro, \& Schmidheiny, 2010). Migration flows may also result in social tensions between groups, and may generate fear of foreign infiltration among natives (Bellini, Ottaviano, Pinelli, \& Prarolo, 2008; Ottaviano \& Peri, 2006; Ozgen, Nijkamp, \& Poot, 2011; Suedekum et al., 2009).

Since the presence of migrants is so essential for urban and regional growth, it is important to know what makes a city an attractive place for highly skilled migrants. This paper aims to shed light on this issue by considering the location choice of highly-educated foreign workers, and how their valuation of urban amenities differs from domestic workers. To do so, we apply a residential location-choice model to estimate the attractiveness of residential locations by low and high-skilled, domestic and foreign workers, and calculate and compare their willingness to pay for each of these amenities. Our location choice model is based on earlier work by Bayer and his coauthors (Bayer, Mcmillan, \& Rueben, 2004), and is estimated on data over location choices of households in the Netherlands. 
The paper is organized as following. In section 2 we will describe relevant and recent researches that studied the valuation of urban amenities and their role as attraction factors, and studies that investigated location choices of individuals, particularly skilled and migrant workers. In Section 3 we discuss the residential sorting model and explain the design of the estimation model. Section 4 describes the data that was used and the variables which were included. Section 5 describes the results of the estimation and section 6 provides discussion and concluding remarks.

\section{The importance of urban amenities as an attraction factors for foreign skilled worker}

In recent years, increasing attention is given to the role of cities as centers of consumption as well as production. This perspective suggests that urban amenities and urban attraction factors are important for the growth of cities (Adamson, Clark, \& Partridge, 2004; Brueckner, 2000; Edward Glaeser, Kolko, \& Saiz, 2001). The perception of cities as consumption centers focuses the analysis of residential location choices on the provision of urban amenities, as they determine the unique characteristics of a city and the utility which individuals derive from them.

Much research is still being conducted around the question of what determines valuation patterns of urban amenities. Valuation of urban amenities differs between groups in the population, based on their specific characteristics such as origin, skill and income levels. These differences influence location decisions of individual households between these groups. The implication is that households are sorted into different cities, or into neighborhoods within a city, based on their individual willingness to pay for the provision of certain urban amenities (Bayer, Ferreira, \& Mcmillan, 2007; Brueckner, 2000; van Duijn \& Rouwendal, 2013).

Assertions that urban amenities are not valued equally by heterogeneous households, and that urban amenities can develop endogenously for social and economic conditions, are emphasized in studies that refer to preferences of migrants. Rodriguez-Pose and Ketterer (2012) examine the role of urban amenities in the process of location choices of migrants in Europe, and find that historical as well as natural amenities are important in determining the attractiveness of regions. They also find that factors such as the presence of a large migrant community, regional wealth and favorable local labor market conditions are relevant in determining the geographical appeal for migrants of EU regions. Aslund (2005), Damm (2012) and Jaeger (2006) study the location choices of international migrants. They do not base the set of alternatives directly on urban amenities but on the effects of social interaction - the existing population demographics, and of the local labor market. Their findings emphasize the importance of existing migrants' community and network, and the expected labor outcome while choosing a migration destination. A local migrants' network is viewed as an attractive amenity for migrants, since it provides information 
about the local labor market at the destination and it assists new migrants in finding jobs (Åslund, 2005; Bauer, Epstein, Gang, \& Al, 2007; Borjas, 1994; Jaeger, 2006; Munshi, 2003).

However, an existing community of migrants should also be considered as an endogenously determined amenity. Namely, a concentration of migrants in a city or neighborhood may be the result, as well as the cause, for migrants' location decisions. This concern was addressed by instrumental variable techniques by Ottaviano and Peri (2006) and Mocetti and Porello (2010), which used the distance to an immigration gateway as an instrument for the current concentration of migrants. Damm (2012) deals with the endogenous concentration of migrants by exploiting a natural experiment in which refugees in Denmark were assigned quasi randomly to municipalities. Hunt and Gauthier-Loiselle (2008) and Niebuhr (2010) instrumented the existing share of skilled migrants by the lagged share of low-skilled migrants, as the shares of both groups are likely to be correlated (some urban amenities appeal to both), but the presence of unskilled migrants is unlikely to be correlated with skilled migrants' effects on innovation and productivity.

Migrants' location decisions are also largely determined by their individual skill levels. Bartel (1989) focuses particularly on the subpopulation of highly-educated migrants and finds that their location decisions may be opposite to those of the rest of the migrant population. For example, she finds that highly skilled migrants from Europe or Asia to the US tend to locate away from areas with a large community from the same ethnic origin. This finding shows that neglecting heterogeneity in personal characteristics within groups of migrants, particularly in skill levels, may lead to biased estimates of their choice of residential locations and their valuation of urban amenities.

Comparing location choices of migrant workers of different skill levels, Gottlieb and Joseph (2006) find that doctorate degree holders have much higher valuation of regional amenities, even in comparison with other highly-skilled migrants. The authors explain this by arguing that doctorate holders have more bargaining power in employment negotiations, permitting them to demand and secure high amenities. In addition, they also find that educated migrants tend to value areas with higher percentages of university graduates, or better-educated cities. Contrary to Gottlieb et al.'s findings, Brown and Scott (2012) find that higher-educated workers (measured as academic degree holders) value recreational and destination labor market amenities similar to the rest of the migrant population. They also find that compared with less-skilled workers, high skilled migrants place a higher value on the benefits of thick labor markets. Highly-educated workers thus appear to be more likely to seek larger labor markets in which they can specialize in their industry and occupation. This may result in higher productivity and wages, which may favor further concentration of human capital from other specialized industry peers. 
Despite the extensive research which was conducted in the field of valuation of urban amenities, and their attraction effect over skilled migrants, it is evident that the complexity of the issue leaves much room for further research. Researchers generally agree that residential decisions are closely dependent on several urban amenities, such as a large labor market, an existing community of migrants, urban scale, accessibility, natural aspects and historical amenities. However, most studies do not provide estimations of the willingness to pay (either positive or negative) for amenities. This paper aims to contribute to the literature by focusing on this issue. The valuation of the marginal willingness to pay for urban amenities has a direct use in urban policy, but it may also help to make a comparison of the preferences and location decisions of groups of domestic and foreign, skilled and low-skilled workers. Understanding whether the decisions of highly educated migrants show more resemblance to those of the low-skilled migrants, or to those of the skilled native workers, would further help focus urban or regional policy that aims to attract skilled migrants.

\section{The Residential sorting model}

\subsection{Methodology}

The most prevalent method to estimate location choices in literature is by using the multinomiallogit (MNL) model. Allowing for a sufficient amount of heterogeneity among the consumers allows aggregate substitution elasticities to be determined by the data, which makes the presence of the independence of irrelevance alternative (IIA) property at the level of the individual decision maker - which has long been regarded as an important drawback - less of a problem. ${ }^{1}$ The MNL-based sorting model is used below to estimate the probabilities for each household $i$ to choose each location $n$, based on the assumption of households' utility maximization. The estimated parameters reveal the valuation of the alternative locations' characteristics. In this respect the sorting model is similar to hedonic regression models which are most commonly used in literature for this purpose. ${ }^{2}$ However, in addition to the average marginal willingness to pay for amenities, which is also revealed by hedonic analysis, the residential sorting model provides the marginal willingness to pay for specific groups of households.

\subsection{The residential sorting model - Design of the model}

\footnotetext{
${ }^{1}$ This was shown by McFadden and Train (McFadden \& Train, 2000) for the mixed (or random coefficient) logit models, in which unobserved heterogeneity is included, but similar arguments can be put forward for a multinomial logit model that refers to a heterogeneous group of decision makers. See Bayer et al. (2004). See Gottlieb et al. (Gottlieb \& Joseph, 2006) for an application of the mixed logit model to migration choices.

${ }^{2}$ See Bayer et al. (Bayer et al., 2007) for a comparison of the sorting model and hedonic price analysis.
} 
We consider a population of households $i=1 . . I$, that chooses a residential location out of a given set of alternatives $n=1 \ldots N$. Household $i$ chooses an alternative location $n$ such that it maximizes its indirect utility, based on the provision of urban amenities $k=1 . . K$ in each location.

$$
M A X U_{i, n}=V_{i, n}+\varepsilon_{i, n}=\sum_{k=1}^{K} \alpha_{i, k} X_{k, n}+\varepsilon_{i, n}, U_{i, n} \geq U_{i, m} \forall n \neq m
$$

Where $V_{i, n}$ denotes the indirect utility of household $\mathrm{i}$ from alternative $\mathrm{n}, X_{k, n}$ denotes the value of the $k$-th characteristic of alternative $n . X_{k, n}$ includes all observed location characteristics, among them are also house prices and share of migrants in a location. $\alpha_{i, k}$ is a household type-specific coefficient which depends on households' individual characteristics:

$$
\alpha_{i, k}=\beta_{0, k}+\sum_{l=1}^{L} \beta_{k, l}\left(Z_{i, l}-\bar{Z}_{l}\right)
$$

Where $Z_{i, l}$ denotes the value of the $l$-th characteristic of household $i, \bar{Z}_{l}$ denotes the sample mean of characteristic 1. Equation (1.1) can therefore be rewritten as:

$$
U_{i, n}=\sum_{k=1}^{K} \beta_{0, k} X_{k, n}+\sum_{k=1}^{K}\left(\sum_{l=1}^{L} \beta_{k, l}\left(Z_{i, l}-\bar{Z}_{l}\right)\right) X_{k, n}+\varepsilon_{i, n}
$$

The first expression on the right-hand side can be interpreted as the indirect utility of the "average household" from location $n$. The second expression is interpreted as the deviation from the mean indirect utility of location $\mathrm{n}$ of household $i$, based on its observed household characteristics. Hence, $\beta_{k, l}$ captures the cross effects between household and characteristics and urban amenities.

As we mentioned above, in practice it is difficult to believe that all relevant location characteristics are observed. Since it is plausible that households' utility is affected by unobserved characteristics, an additional constant term $\xi_{n}$ is introduced in the model in order to capture these specific location characteristics.

$$
U_{i, n}=\sum_{k=1}^{K} \beta_{0, k} X_{k, n}+\sum_{k=1}^{K}\left(\sum_{l=1}^{L} \beta_{k, l}\left(Z_{i, l}-\bar{Z}_{l}\right)\right) X_{k, n}+\xi_{n}+\varepsilon_{i, n}
$$

However, introducing the term $\xi_{n}$ creates an additional problem, since the unobserved location characteristics are most likely correlated with the observed characteristics, particularly with the housing price. Ignoring this would result a bias in the estimates of $\beta_{0, k}$. To address this endogeneity problem, we follow Berry et al's (Berry, Levinsohn, Pakes, \& Berry, 1995) method and estimate the model in two steps. We begin by rewriting the model in equation (1.4) as:

$U_{i, n}=\delta_{n}+\sum_{k=1}^{K}\left(\sum_{l=1}^{L} \beta_{k, l}\left(Z_{i, l}-\bar{Z}_{l}\right)\right) X_{k, n}+\varepsilon_{i, n}$

With:

$\delta_{n}=\sum_{k=1}^{K} \beta_{0, k} X_{k, n}+\xi_{n}$

In the first step of the estimation, we estimate equation (1.5) as a multinomial-logit model, assuming that the individual error is randomly drawn and independently and identically 
distributed (IID). The estimation is conducted by maximum-likelihood procedure, in which we estimate the vector of individual coefficients $\beta_{k, l}$ and the vector of mean indirect utilities from each location $\delta_{n}$. In the second step of the estimation, we analyze the components of $\delta_{n}$, by estimating equation (1.6) in a 2 SLS model with instrumental variables.

The estimation of the first step is largely dependent on the equilibrium condition, according which the demand should equal the supply of houses in each location $n$. After defining the indirect utility function in (1.5), we calculate the probabilities of each household $i$ to choose location $n$ (denoted as $P r_{i, n}$ ), by estimating it as a MNL model using a maximum-likelihood procedure:

$\operatorname{Pr}_{i, n}=\frac{e^{V_{i, n}}}{\sum_{n=1}^{N} e^{V_{i, n}}}$

The estimation of the first step results in a set of choice probabilities. Imposing an equilibrium restriction, we require that the sum of these choice probabilities would be equal to the existing housing stock in each location $\left(S_{n}\right)$.

$\sum_{i=1}^{I} \operatorname{Pr}_{i, n}=S_{n}$

The estimated coefficients $\beta_{k, l}$, which indicate the valuation of household with characteristic $l$ for location characteristic $k$, and $\delta_{n}$, which indicates the mean indirect utility from location $n$, are iteratively adjusted to reflect this equilibrium condition (Berndt, Hall, Hall, \& Hausman, 1974).

In the second step, the estimated $\delta_{n}$ are further analyzed and are now explained by a set of location characteristics in a 2 SLS regression. In this step we instrument the price and share of migrants' variables in order to address the issue of endogeneity. The computation of these instrumental variables will be discussed in the following section.

\subsection{Endogeneity and the use of instrumental variables}

Since house prices equalize demand and supply, they are likely correlated with the unobserved characteristics that affect location choices. Neglecting to consider these unobserved factors may results in bias in the estimation of choice probabilities and biased coefficients. Here, we follow Bayer et al.'s (2004) approach for instrument construction and construct a price instrument assuming no correlation exists with unobserved location heterogeneity. ${ }^{3}$ A similar endogeneity concern occurs in relation to endogenous amenities like the share of migrants located in a city, which is also determined in part by the unobserved amenities. As mentioned, the concentration of migrants was previously instrumented by exogenous variables such as an historical immigrant "gateway", through which historical immigration flows have entered the country (Mocetti \&

3 (Bayer et al., 2004; Klaiber \& Phaneuf, 2010; van Duijn \& Rouwendal, 2013) for more discussion. 
Porello, 2010; Ottaviano \& Peri, 2006). Although this variable might be suitable to explain location choices over a large geographical area like the United States, it is practically inapplicable in a small country like the Netherlands. Therefore, we construct an instrument for the share of migrants in municipalities by using the same procedure as in the construction of the price instrument. Namely, we construct the counterfactual share of migrants, as it would have been if there were no unobserved municipal characteristics.

Therefore, the second step of the estimation includes instrumental variables for both prices and the share of migrants. As was done by Bayer et al (2004) and Van Duijn and Rouwendal (2013), we construct the instruments based on the sorting model and existing data. We do so by assuming no unobserved neighborhood characteristics $\left(\xi_{n}=0\right)$. Following this, we simultaneously compute the price and share of migrants' vectors which would clear the market under this restriction. Intuitively, the price instrument is the set of prices that would prevail in equilibrium if the only amenities relevant for location decisions are those observed in the model and the instrument for the share of migrants is the share that would be observed in this situation. The computed instruments are valid since they are correlated with the original price and share of migrants' variables respectively, and they are defined such that they would have zero correlation with unobserved characteristics.

\subsection{Spatial extensions}

The Randstad study area is an urban cluster characterized by high population density and continuity in the urban landscape. Municipal borders are irregular and do not represent a barrier (they are hardly noticeable), which raises the issue of spatial interdependence between the different municipalities. Households can reside in one municipality and enjoy the amenities of the neighboring municipalities, without experiencing high travel costs. To address this challenge we include a spatial lag in the explanatory variables, by adding a spatially-weighted average of amenity levels in the neighboring municipalities $\left(P X_{i, k}\right)$. The weights are determined by a rowstandardized inverse-distance between municipality $i$ to all other municipalities $j=1 \ldots n, j \neq i$.

$P X_{i, k}=\sum_{j=1, j \neq i}^{n} \frac{\frac{1}{d_{i, j}}}{\sum_{j} \frac{1}{d_{i, j}}} * X_{j, k}$

Additionally, we also consider the fact the unobserved amenities may also be spatially correlated, and therefore, following Anselin (Anselin, 1988) and Anselin et al. (Anselin, Bera, Florax, \& Yoon, 1996) we test for spatial correlation in the residuals of the model using Moran's I and Lagrange-multiplier test (see results in Table 1). 
Table 1 - Test statistics for spatial dependence

\begin{tabular}{lcc}
\hline & Statistic & p-value \\
\hline Moran's I & -0.051 & 0.419 \\
Lagrange multiplier & 0.033 & 0.855 \\
Lagrange multiplier (Robust) & 0.076 & 0.783 \\
\hline
\end{tabular}

The statistics values obtained for Moran's I and the Lagrange-multiplier test for residual spatial correlation show little evidence that such correlation exists. Although these values suggest that we can estimate the model without considering spatial correlation in the model's residuals, we include an additional estimation of the model using Drukker et al.'s (Drukker, Egger, \& Prucha, 2013; Drukker \& Prucha, 2011) GMM/IV estimation method, for the purpose of robustness check. The GMM/IV is a two-step estimation of spatial autoregressive disturbances model with consideration in endogenous regressors, and its formulation can be found in Drukker et al. (2011, 2013).

\subsection{Calculations of the marginal willingness to pay for urban attributes}

Estimation of the sorting model produces a set of coefficients that determine the valuation of each of the observed attributes by the average household in the sample as well as for specific types of households. We use these estimated coefficients to compute the marginal willingness to pay for the observed location attributes. The marginal willingness to pay for characteristic $n$ by a household belonging to group $l$ is the change in the price that keeps utility constant after a small change in the value of the $k$-th characteristic:

$\frac{\partial P_{n}}{\partial X_{k, n}}=\frac{\left(\beta_{0, k}+\beta_{k, l}\left(Z_{i, l}-\overline{Z_{l}}\right)\right)}{\left(\beta_{0, p}+\beta_{p, l}\left(Z_{i, l}-\overline{Z_{l}}\right)\right)} P_{n}$

Household specific preferences are designed to have zero mean, this implies that the MWTP of the average household is:

$\frac{\partial P_{n}}{\partial X_{k, n}}=\frac{\beta_{0, k}}{\beta_{0, p}} P_{n}$

Computing the average and household type-specific MWTP, we are able to estimate the monetary value which is placed on various urban amenities by each group in the population, based on skill level and origin. This allows measuring which amenities are perceived to be more valuable and attractive to each of the groups, explaining their location patterns and comparing the differences in preferences for urban amenities between them. 


\section{Data and study areas}

\subsection{Databases}

For residential location choices data we use Netherlands housing research survey (WoON) 2012, which was conducted as a joint co-operation between the Ministry of the Interior and Kingdom Relations (BZK) and the Dutch Central Bureau of Statistics (CBS). Data over municipality characteristics is also taken from the Dutch CBS.

\subsection{Randstad municipalities analysis}

The western area of the Netherlands is characterized by high levels of urbanization, and it is in fact an agglomeration of cities (the "Randstad"). Among the cities which are included in the Randstad are the four largest cities in the Netherlands - Amsterdam, Rotterdam, Den-Haag (The Hague, also known as 's-Gravenhage) and Utrecht. The region also includes other populated municipalities such as Almere, Zaanstad, Amersfoort, Leiden, Zoetermeer and Dordrecht. Despite its high overall population density, the centre of the Randstad remains relatively rural ( "De Groene Hart" - The Green Heart), and its municipalities maintain an agricultural character. The borders of the Randstad are not officially specified, and in this analysis we included 135 different municipalities (see appendix A.1 for the full list), all within a short commuting distance from the main population centers in the four largest cities (see the map in Figure 1).

Since the Randstad is relatively small and urbanized, commuting is common and individuals may live in one municipality but work and enjoy amenities in other nearby municipality. To address the issue of spatial interdependence we introduce spatial data in the model using spatial matrixes, which were constructed based on contiguity of neighboring municipality as well as on inverse distance between municipality centroids. 


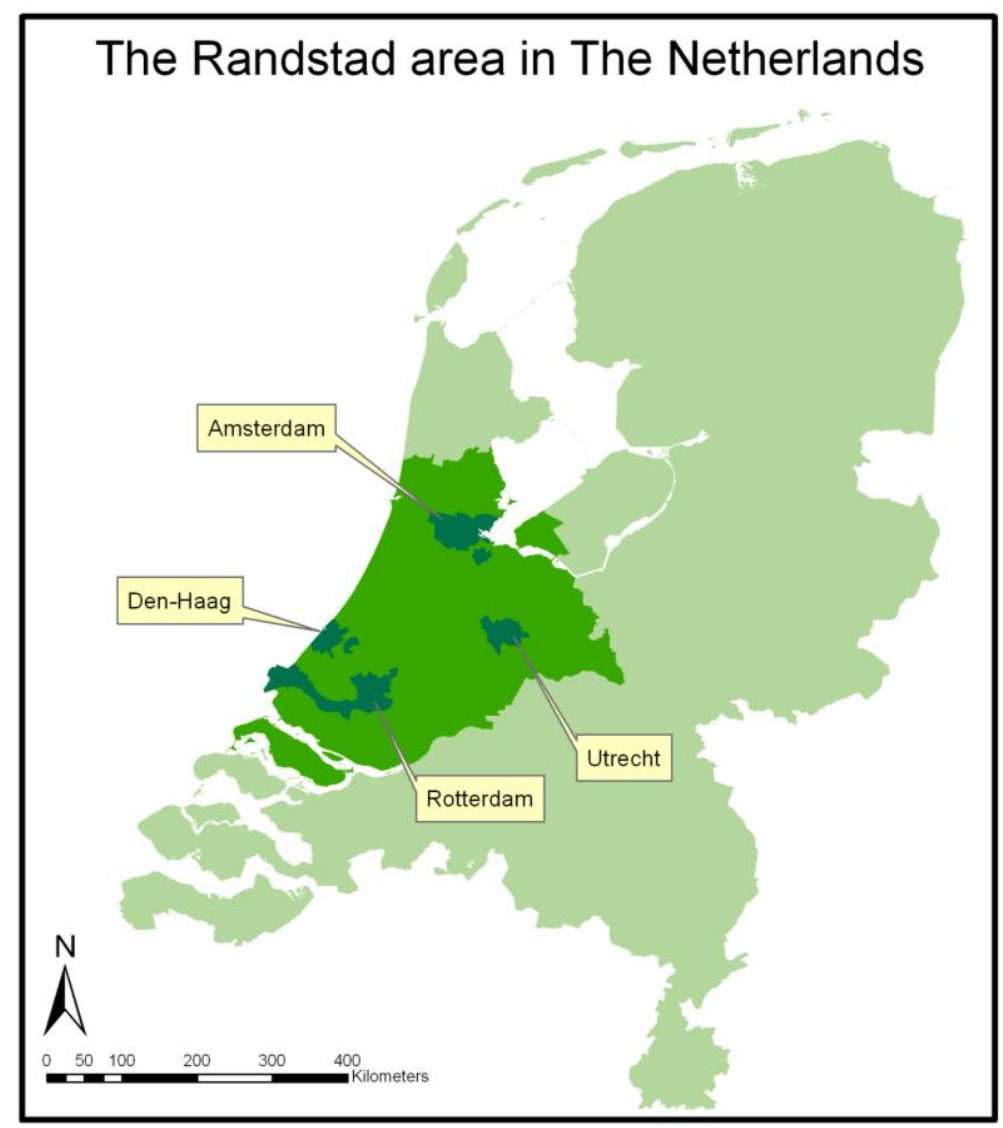

Figure 1 - The Randstad study area within the Netherlands.

\subsection{Variables included - Household characteristics}

Households are identified based on several characteristics, as indicated by each respondent in the WoON 2012 survey. We identify respondent's age, a dummy variable indicating whether the household includes children, and the logarithm of household income. We also add additional dummy variables indicating whether the respondent is high-skilled domestic worker, low-skilled migrant or a high-skilled migrant. Since these variables play a key role in our analysis, we discuss them in some detail.

The identification of a respondent's migrant status or skill level is somewhat uncertain. While skill level is more clearly determined, as we define a person as "skilled" whether he or she indicates to have obtained at least a professional or university degree, inaccuracies may still exist as some may be more inclined to indicate a different skill level. For instance, students in advanced progress of obtaining a degree may indicate themselves as degree holders.

This issue becomes more complicated with the case of migrants status. We identify respondents as 'migrants' if they have indicated themselves to be not of Dutch descent. This broad definition 
includes recent immigrants, but it also includes those who were born in the Netherlands and whose parents (or perhaps grandparents) arrived to the Netherlands as immigrants. The definition of a respondent as a native may also be inaccurate. For example, respondents who were not born in the Netherlands but were living there for many years may view themselves as natives. This issue leaves much area for interpretation by respondents and researchers alike, and makes the identification of the group of migrants quite difficult. Nonetheless, we may argue that this definition can be viewed as an advantage, and it may even better serve the purpose of the research. The reason is that when a respondent views herself as a migrant regardless of whether she was born in the Netherlands or not, her preferences in housing may be more similar to those who broadly define themselves as migrants rather than those who define themselves as natives. In this sense, the self-identification as migrants may prove to be more suitable for the research.

According to WoON 2012 survey data, approximately 24\% of the survey respondents who live in the Randstad area are of foreign origin (6,322 respondents). Areas with the highest concentration of migrants are Amsterdam metropolitan area (Groot Amsterdam) and The Hague metropolitan area (Agglomeratie 's-Gravenhage), both with approximately $31 \%$ of respondents indicating themselves as migrants. Areas with the lowest concentration of migrants were Delft-Westland and East Zuid-Holland (Oost Zuid-Holland), with $11 \%$ and $13 \%$ migrants respectively.

The Randstad area also has a large proportion of skilled respondents; approximately $45 \%$ of the skilled respondents in WoON 2012 have reported to live in one of the Randstad municipalities.

Out of the skilled population in the Randstad, approximately $21 \%$ (or 1,832) respondents are skilled migrants. Skilled migrants also form $29 \%$ of total migrant respondents in the province.

\subsection{Variables included - Urban amenities}

In order to explain the location choice of different population groups in the Randstad area, we included several amenities as explanatory variables. Following the findings of previous researches, we included recreational, cultural and natural amenities, as well as amenities which stress labor possibilities, accessibility and urban scale. As a proxy for existence of migrant networks and presence of cultural and ethnic goods, we also include the share of migrants in each municipality as explanatory variable. Average municipality housing prices are also included in our analysis. Both prices and the share of migrants are instrumented as explained in section 3.3.

Housing prices are calculated using hedonic regressions, which were based on data gathered from NVM, the Dutch real estate association. Data over the share of migrants in each municipality is taken from the Dutch Central Bureau of Statistics (CBS). According to the Dutch CBS definition, a migrant is defined as a person which at least one of his/her parents was not born in the Netherlands. This broad definition is quite different from the WoON data definition of a foreigner, according to which respondents are required to indicate themselves whether they 
consider themselves as belonging to a non-Dutch ethnic group. Although the differences between definitions may create problems, they are not critically restrictive since the CBS definition is used to determine the share of a community of migrants as an alternative location's characteristics, while the WoON definition is used to characterize individuals' preferences.

Consistently with the discussion presented in the literature regarding the possible positive and negative effects of an existing foreign community, we introduce the share of migrants in the model both directly and as a square term. The purpose of this specification is to identify whether the marginal effect of an increase in the share of migrants differs between lower and higher levels of shares. In accordance with the literature, we expect that the positive effects of an existing community of migrants are dominant when the share of migrants is relatively low, and the negative become dominant where the share of migrants is higher.

To represent culture and recreation we use the number of national monuments in the municipalities (see appendix A.1), which have shown by Van Duijn and Rouwendal (2013) to be a good proxy for historical and cultural heritage, as well as other recreational and commercial activities which are attracted to historical scenery like cafes and restaurants. The data is taken from the Dutch Cultural Heritage Agency (RCE). We also use the area of nature coverage in a municipality as an indication for natural scenery amenity in a municipality, which is assumed to have positive valuation due its recreational and aesthetic attributes.

Since previous researchers found that labor market conditions matter for location choices of migrants, particularly with high education, we added the number of jobs in a municipality, and its level of accessibility (see appendix A.1). We also included a rail-accessibility variable, which is measured by the average distance of all residents in an area to the nearest train station (available from the Dutch CBS). Much like the number of jobs variables, which represents the "thickness" of the labor market, we also add the location-quotient of employment in information and communication (ICT) industries. A relatively high concentration of these knowledge intensive industries (approximately 60\% of employees in this sector have a university or professional degree) in a specific municipality is assumed to be particularly appealing for skilled workers of foreign origin. The ICT sector is over represented (LQ of 3.47) in the Den-Haag metropolitan area, Het Gooi (North-eastern Randstad), Utrecht, Amsterdam and Haarlem areas. In the rest of the sub-regions of the Randstad, Notably in Groot-Rijnmond where Rotterdam is located, ICT industry is quite underrepresented (see appendix A.1).

In addition, we also attempt to proxy the urban scale of a municipality using the number of households variable. As was previously noted by Gottlieb and Joseph (2006), who include city size as a similar variable to reflect urban scale, this inclusion creates a problem as urban scale is correlated both with the provision of recreational amenities (such as theatres, restaurants and major sport leagues) and with a thick labor market. Therefore, its coefficient is likely to have a 
positive bias. Examining the variables' correlation table (see Table 2) we find that the number of households is too correlated with most variables to be included in the estimation.

Table 2 - Correlation between urban amenities variables

\begin{tabular}{|l|r|r|r|r|r|r|r|r|}
\hline & In(price) & $\begin{array}{c}\text { Perc. } \\
\text { Mig }\end{array}$ & Accessibility & Jobs & Monuments & nature & $\begin{array}{c}\text { LQ } \\
\text { (ICT) }\end{array}$ & $\begin{array}{l}\text { Number of } \\
\text { Households }\end{array}$ \\
\hline In(price) & 1.00 & & & & & & & \\
\hline Perc. Mig & 0.06 & 1.00 & & & & & & \\
\hline Accessibility & -0.31 & -0.47 & 1.00 & & & & & \\
\hline Jobs & 0.02 & 0.68 & -0.19 & 1.00 & & & & \\
\hline Monuments & 0.19 & 0.45 & -0.11 & 0.79 & 1.00 & & & \\
\hline nature & 0.44 & 0.10 & -0.10 & -0.07 & -0.05 & 1.00 & & \\
\hline LQ (ICT) & 0.42 & 0.26 & -0.22 & 0.13 & 0.10 & 0.21 & 1.00 & \\
\hline Number of Households & 0.00 & 0.70 & -0.20 & 0.99 & 0.80 & -0.06 & 0.12 & 1.00 \\
\hline
\end{tabular}

Moreover, due to its high correlation with the number of jobs (99\%), both variables may serve as a proxy for urban scale. The fact that urban scale may be embodied in many variables further emphasizes the problem of endogeneity in urban amenities variables, and the concern that it is difficult to identify amenities which are independent from other urban attraction factors.

\section{Results}

\subsection{First step estimation results}

Table 3 describes the variables which were used in the estimation of the sorting model, as explained in sections 3 and 4 .

\section{Table 3 - Specification description}

\begin{tabular}{|c|c|c|}
\hline Individual characteristics $\left(Z_{1}\right)$ & Alternative characteristics $\left(\mathrm{X}_{\mathrm{k}}\right)$ & $\begin{array}{l}\text { Spatial lags in the } \\
\text { explanatory variables }\left(\mathrm{PX}_{\mathrm{k}}\right)\end{array}$ \\
\hline $\begin{array}{ll}\text { - } & \text { Age of respondent } \\
\text { - } & \text { Dummy if has kids } \\
\text { - } & \text { Income } \\
\text { - } & \text { Skilled native dummy } \\
\text { - } & \text { Low-skilled migrant } \\
\text { - } & \text { dummy } \\
\text { Skilled migrant Dummy }\end{array}$ & $\begin{array}{ll}\text { - } & \ln \text { (Price) } \\
\text { - } & \text { Share of migrants } \\
\text { - } & \text { Share of migrants square) } \\
& \text { Accessibility (Distance from } \\
& \text { intercity train station } \\
\text { - } & \text { Number of jobs ('000) } \\
\text { - } & \text { Monuments } \\
\text { - } & \text { LQ (ICT) } \\
\text { - } & \text { Percentage of nature coverage. }\end{array}$ & $\begin{array}{l}\text { Included for all alternative } \\
\text { characteristics variables except } \\
\text { for prices. }\end{array}$ \\
\hline
\end{tabular}


The results of first step include the coefficients of the cross effects between individual and location characteristics, as well as the vector of location-specific constants, which indicate the indirect utility of the mean household from each of the alternatives. The estimation shows that the coefficients of the households-amenities cross effects are different from each other (see Table 4). This serves as a preliminary demonstration that valuation of urban amenities differs between different subgroups of the population.

\section{Table 4 - First step results}

\begin{tabular}{|c|c|c|c|c|c|c|}
\hline & Age & Kids dummy & In (income) & Native Skill & Mig-Lowskill & Mig-Skill \\
\hline \multirow[t]{2}{*}{ In (Price) } & -0.00191 & $-0.92884 * * *$ & $-0.52301 * * *$ & $2.064872 * * *$ & -0.25085 & $1.532261 * * *$ \\
\hline & $(0.0038)$ & $(0.1482)$ & $(0.0898)$ & $(0.1616)$ & $(0.1814)$ & $(0.2256)$ \\
\hline \multirow[t]{2}{*}{ P.mig } & $-0.00140 * * *$ & $-0.04581 * * *$ & $-0.02218 * * *$ & $0.059102 * * *$ & $0.103589 * * *$ & $0.119127 * * *$ \\
\hline & $(0.0001)$ & $(0.0055)$ & $(0.0031)$ & $(0.0060)$ & $(0.0074)$ & $(0.0098)$ \\
\hline \multirow[t]{2}{*}{ P.mig (square) } & $0.000020 * * *$ & $0.000618 * * *$ & -0.00001 & $-0.00049 * * *$ & $-0.00097 * * *$ & $-0.00127 * * *$ \\
\hline & $(0.0000)$ & $(0.0001)$ & $(0.0000)$ & $(0.0001)$ & $(0.0001)$ & $(0.0002)$ \\
\hline \multirow[t]{2}{*}{ Accessibility } & $-0.00066 * * *$ & $-0.01568 * * *$ & 0.003155 & $-0.01007 *$ & 0.001465 & $-0.05792 * * *$ \\
\hline & $(0.0001)$ & $(0.0049)$ & $(0.0034)$ & $(0.0055)$ & $(0.0072)$ & $(0.0095)$ \\
\hline \multirow[t]{2}{*}{ Jobs } & $-0.00005 * * *$ & $-0.00114 * * *$ & 0.000080 & -0.00031 & 0.000290 & $-0.00183 * * *$ \\
\hline & $(0.0000)$ & $(0.0003)$ & $(0.0001)$ & $(0.0003)$ & $(0.0003)$ & $(0.0004)$ \\
\hline \multirow[t]{2}{*}{ Monuments } & $0.000002 * * *$ & $0.000059 * * *$ & $0.000072 * * *$ & $-0.00008 * * *$ & $0.000059 * * *$ & $0.000104 * * *$ \\
\hline & $(0.0000)$ & $(0.0000)$ & $(0.0000)$ & $(0.0000)$ & $(0.0000)$ & $(0.0000)$ \\
\hline \multirow[t]{2}{*}{ Nature } & $0.000181 * * *$ & $-0.00634 * * *$ & $0.006819 * * *$ & $-0.00741 * * *$ & $0.004789 * * *$ & $-0.00542 * * *$ \\
\hline & $(0.0000)$ & $(0.0011)$ & $(0.0006)$ & $(0.0011)$ & $(0.0014)$ & $(0.0018)$ \\
\hline \multirow[t]{2}{*}{ LQ (ICT) } & $0.002917 * * *$ & -0.02809 & $0.095225 * * *$ & -0.00471 & $0.051951 * *$ & $0.107249 * * *$ \\
\hline & $(0.0005)$ & $(0.0196)$ & $(0.0118)$ & $(0.0223)$ & $(0.0225)$ & $(0.0288)$ \\
\hline \multirow[t]{2}{*}{ P.mig (Spatial lag) } & $0.009090 * * *$ & $0.328049 * * *$ & $0.190527 * *$ & $0.405741 * * *$ & -0.18393 & $0.944389 * * *$ \\
\hline & $(0.0030)$ & $(0.1173)$ & $(0.0803)$ & $(0.1356)$ & $(0.1501)$ & $(0.2347)$ \\
\hline \multirow[t]{2}{*}{ P.mig (square) (Spatial lag) } & $-0.00016 * *$ & $-0.00772 * *$ & $-0.00375^{*}$ & $-0.01144 * * *$ & 0.004802 & $-0.01860 * * *$ \\
\hline & $(0.0000)$ & $(0.0031)$ & $(0.0021)$ & $(0.0035)$ & $(0.0040)$ & $(0.0059)$ \\
\hline \multirow[t]{2}{*}{ Accessibility (Spatial lag) } & $0.002431 * *$ & 0.033195 & $0.054198 * *$ & $0.115608 * * *$ & -0.07339 & $0.335551 * * *$ \\
\hline & $(0.0010)$ & $(0.0377)$ & $(0.0259)$ & $(0.0421)$ & $(0.0521)$ & $(0.0676)$ \\
\hline \multirow[t]{2}{*}{ Jobs (Spatial lag) } & -0.00009 & 0.008361 & -0.00295 & $0.030109 * * *$ & -0.01474 & 0.002236 \\
\hline & $(0.0002)$ & $(0.0089)$ & $(0.0056)$ & $(0.0098)$ & $(0.0110)$ & $(0.0145)$ \\
\hline \multirow[t]{2}{*}{ monuments (Spatial lag) } & $0.000089 * * *$ & $0.001479 * * *$ & $0.002323 * * *$ & $-0.00481 * * *$ & $0.003272 * * *$ & $0.002601 * * *$ \\
\hline & $(0.0000)$ & $(0.0005)$ & $(0.0003)$ & $(0.0006)$ & $(0.0006)$ & $(0.0008)$ \\
\hline \multirow[t]{2}{*}{ nature (Spatial lag) } & $0.000596 * *$ & $-0.01740 *$ & 0.002991 & -0.00208 & 0.010198 & 0.009520 \\
\hline & $(0.0002)$ & $(0.0093)$ & $(0.0063)$ & $(0.0102)$ & $(0.0120)$ & $(0.0163)$ \\
\hline \multirow[t]{2}{*}{ LQ (ICT) (Spatial lag) } & $-0.02917 * * *$ & $0.299723 * * *$ & $-0.53668 * * *$ & $0.600603 * * *$ & $-0.80722 * * *$ & -0.22486 \\
\hline & $(0.0027)$ & $(0.1067)$ & $(0.0669)$ & $(0.1184)$ & $(0.1302)$ & $(0.1545)$ \\
\hline
\end{tabular}

$\mathrm{N}=27163$

Robust standard errors in parentheses

$* * * \mathrm{p}<0.01, * * \mathrm{p}<0.05, * \mathrm{p}<0.1$

Note: Alternative specific constants for each Randstad municipality are included in the model and are reported separately in appendix B.1. 
Examining the results of first step estimation, we first observe that skilled respondents have a positive and significant cross effect with prices, compared with the other groups. This does not necessarily suggests that these groups value higher housing prices as a location attribute, but rather that these groups are less sensitive to housing prices. The results also show positive and significant cross coefficients of existing community of migrants among both skilled natives and migrant respondents of both skill levels, where the migrants' cross coefficient is higher. This indicates that these groups are likely to have a higher than average valuation of strong presence of migrants in a municipality. Introducing the square term of migrant community share, we see a small negative and significant coefficient among migrants, indicating that higher shares of migrants in a municipality may result in a negative valuation.

Examining the cross coefficients of the number of jobs in the municipality, values seem to be relatively low, particularly among skilled native who have a negative cross coefficient, indicating a lower sensitivity to the number of jobs or to the urban scale of the municipality. These results can be explained by the cross coefficients of the spatial lag, or the number of jobs in neighboring municipalities. Expectedly, the values of these coefficients are generally higher, especially for the skilled groups of both local and migrant respondents. This corresponds with higher preferences of skilled workers to reside in proximity to a large labor market and enjoying its urban-scale related amenities, without actually residing there.

Regarding the valuation of a concentration of ICT employment, the results show positive and significant coefficients among migrants of both skill level groups, with a much stronger valuation among skilled migrants. The results also show a negative and significant coefficient among skilled respondents and a positive coefficient among respondents with higher income levels. Since the ICT industry is skill-intensive, this result is somewhat surprising. One possible explanation is that the LQ variable refers to a COROP area (NUTS3), which incorporates several municipalities. This means the industry may be concentrated in only one municipality within the COROP area, which would make the rest of the municipalities in the COROP less attractive for skilled workers.

Cross coefficients of monuments show that all groups are sensitive to these amenities. Somewhat surprisingly, the indicator for monuments in neighboring municipalities has even larger coefficients than those for the number of monuments in the municipality of residence. These results are also repeated in the preference for natural and recreational amenities, where among all groups preferences for natural amenities in neighboring municipalities are found to be stronger. 


\subsection{Second step estimation results}

Table 5 describes the results of three model specifications - The OLS model, the 2SLS model where prices and share of migrants are instrumented, and the GMM/IV model for spatial autocorrelation in the residual, in the presence of endogenous regressors.

\section{Table 5 - Second step results}

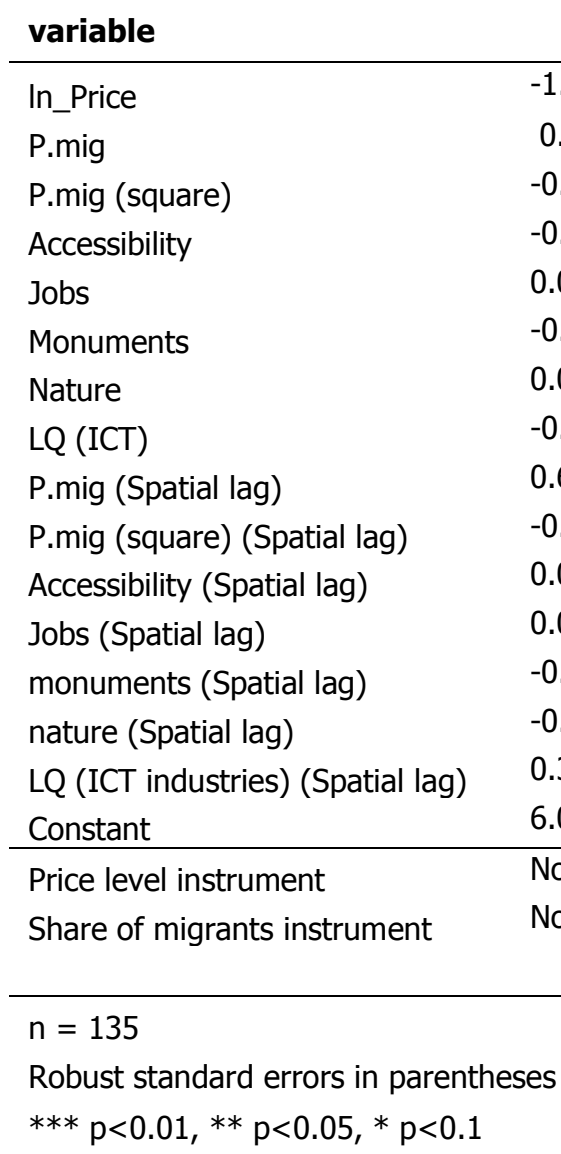

(1)

(2)

OLS (se)

$-1.3412(0.473553) * * *$

$0.163(0.02166)^{* * *}$

$-0.0032(0.000575) * * *$

$-0.0086 \quad(0.013818)$

$0.0127 \quad(0.001923) * * *$

$-0.0001 \quad(0.000123)$

$0.0038 \quad(0.003834)$

$-0.0473(0.07795)$

$0.6215(0.363302)^{*}$

$-0.0149 \quad(0.009951)$

$0.0705 \quad(0.105852)$

$0.0318 \quad(0.026278)$

$\begin{array}{ll}-0.0025 & (0.001699)\end{array}$

$-0.051 \quad(0.035821)$

$0.361 \quad(0.424465)$

$6.0811 \quad$ (5.795729)

No

No
2SLS (se)

\begin{tabular}{llll}
\multicolumn{2}{c}{ 2SLS (se } & \multicolumn{2}{c}{ GMM $/$ IV (se) } \\
-5.2204 & $(0.592238)^{* * *}$ & -5.2055 & $(1.195986)^{* * *}$ \\
0.172 & $(0.027089)^{* * *}$ & 0.1711 & $(0.027197)^{* * *}$ \\
-0.0039 & $(0.000719)^{* * *}$ & -0.0039 & $(0.000748)^{* * *}$ \\
-0.0184 & $(0.017281)$ & -0.0185 & $(0.017646)$ \\
0.011 & $(0.002405)^{* * *}$ & 0.0109 & $(0.002445)^{* * *}$ \\
0.0004 & $(0.000154)^{* *}$ & 0.0004 & $(0.000195)^{*}$ \\
0.0168 & $(0.004795)^{* * *}$ & 0.0167 & $(0.005925)^{* * *}$ \\
0.0212 & $(0.097486)$ & 0.0097 & $(0.099386)$ \\
1.3812 & $(0.454356)^{* * *}$ & 1.3378 & $(0.502419)^{* * *}$ \\
-0.0274 & $(0.012445)^{* *}$ & -0.0264 & $(0.013068)^{* *}$ \\
0.0853 & $(0.132382)$ & 0.0832 & $(0.13471)$ \\
0.0161 & $(0.032865)$ & 0.0147 & $(0.033811)$ \\
-0.0001 & $(0.002125)$ & -0.000025 & $(0.002288)$ \\
-0.1143 & $(0.044798)^{* *}$ & -0.1111 & $(0.048484)^{* *}$ \\
0.7951 & $(0.530848)$ & 0.8264 & $(0.554267)$ \\
45.8762 & $(7.248299)^{* * *}$ & 46.0308 & $(12.976206)^{* * *}$ \\
Yes & & \multicolumn{3}{l}{ Yes } \\
Yes & & Yes & \\
& & Spatial & Rho = 0.0538
\end{tabular}

GMM/IV (se)

(3)

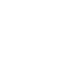


As for the percentage of migrants, the linear term was found to have a positive effect, while the square term was found to have a small but significant negative coefficient. The interpretation of this finding is that the percentage of migrants is found to be valued positively by the average household, but its valuation decreases in higher levels.

The results of the spatially-lagged amenities are found to be statistically insignificant for most amenities. Among the spatial-lag variables, the percentage of migrants' variables stands out. It appears that these coefficients are both statistically significant, as well as estimated with much higher values compared with the non-lagged variables. The interpretation of this finding is that having a large percentage of migrants in nearby municipalities is valued very positively, and it increases the expected attractiveness of a municipality much more compared to having large percentage of migrants in the municipality of choice itself. The spatially-lagged variable of the percentage of migrants squared also has a higher coefficient value compared to the non-lagged variable. This suggests that also under spatial lags the positive effect of a large community of migrants is declining in higher levels.

\subsection{Marginal willingness to pay for urban amenities}

Having estimated the two steps of the residential sorting model, we are able to use the coefficients in order to calculate the marginal willingness to pay for each of the amenities included (as specified in section 3.4). The calculation is based on the coefficients obtained by the estimation of the 2SLS, as specified in column 2 of Table 5. In the process of calculation we distinguish the valuation of each of the amenities by dividing the sample into four groups based on skill and origin- low-skilled natives, high-skilled natives, low-skilled migrants and highskilled migrants.

Table 6 - Willingness-to-pay for a one percent increase of migrants in the municipal population (in Euro)

\begin{tabular}{clllll} 
P.mig & AWTP & $\begin{array}{l}\text { Native-Low } \\
\text { education }\end{array}$ & $\begin{array}{l}\text { Native - High } \\
\text { education }\end{array}$ & $\begin{array}{l}\text { Migrant - Low } \\
\text { education }\end{array}$ & $\begin{array}{l}\text { Migrants - High } \\
\text { education }\end{array}$ \\
\hline $\mathbf{0}$ & $7,561.7$ & $5,205.9$ & $11,709.0$ & $8,913.2$ & $13,470.8$ \\
$\mathbf{5}$ & $5,837.5$ & $3,804.2$ & $9,230.7$ & $7,198.6$ & $10,878.8$ \\
$\mathbf{1 0}$ & $4,113.4$ & $2,402.5$ & $6,752.3$ & $5,484.0$ & $8,286.8$ \\
$\mathbf{1 5}$ & $2,389.2$ & $1,000.7$ & $4,274.0$ & $3,769.4$ & $5,694.8$ \\
$\mathbf{2 0}$ & 665.0 & -401.0 & $1,795.6$ & $2,054.8$ & $3,102.8$ \\
$\mathbf{2 5}$ & $-1,059.1$ & $-1,802.8$ & -682.7 & 340.2 & $-2,0.8$ \\
$\mathbf{3 0}$ & $-2,783.3$ & $-3,204.5$ & $-3,161.1$ & $-1,374.4$ & $-4,673.3$ \\
$\mathbf{3 5}$ & $-4,507.5$ & $-4,606.2$ & $-5,639.4$ & $-3,088.9$ & $-7,265.3$ \\
$\mathbf{4 0}$ & $-6,231.6$ & $-6,008.0$ & $-8,117.8$ & $-4,803.5$ & $-9,857.3$ \\
$\mathbf{4 5}$ & $-7,955.8$ & $-7,409.7$ & $-10,596.1$ & $-6,518.1$ & $-12,449.3$ \\
\hline $\mathbf{5 0}$ & $-9,680.0$ & $-8,811.4$ & $-13,074.5$ & $-8,232.7$ & \\
\hline
\end{tabular}




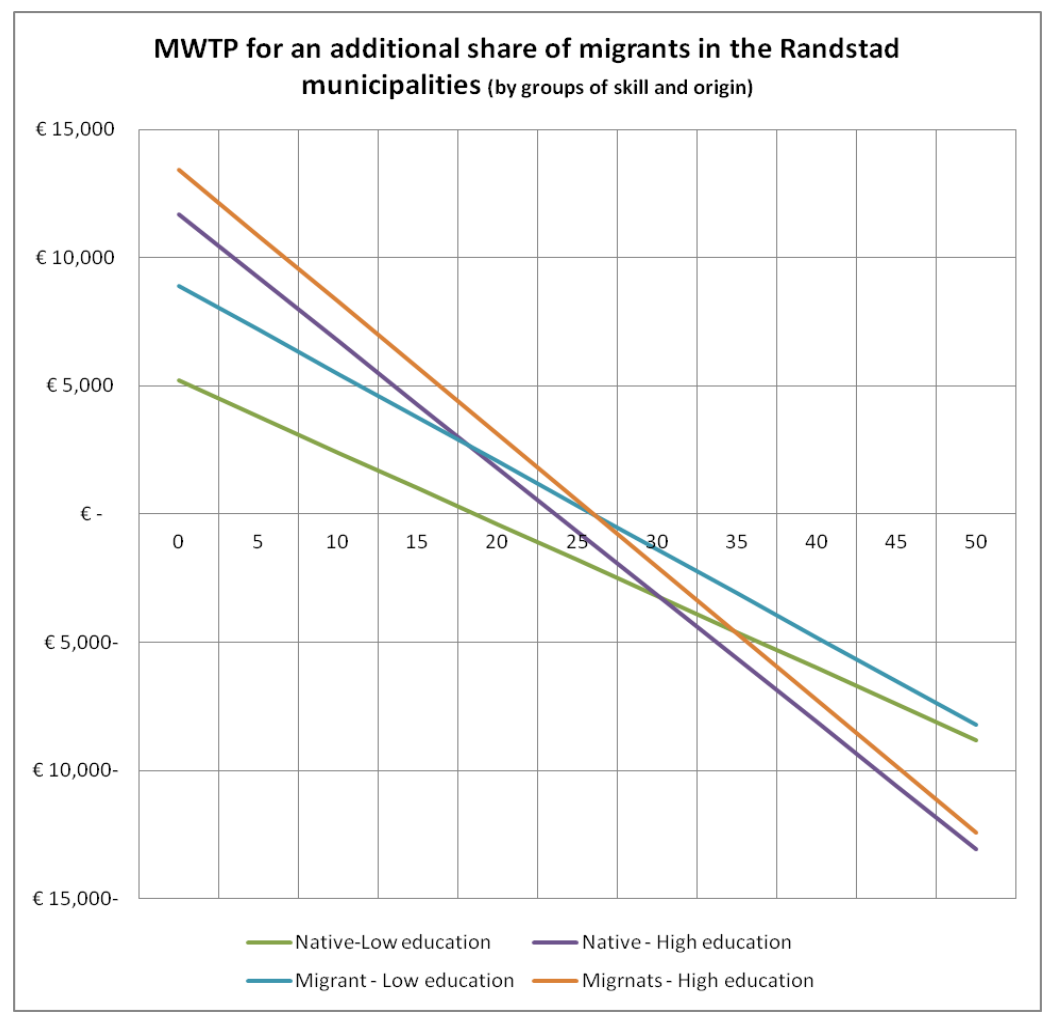

\section{Figure 2 - MWTP for an additional share of migrants in Randstad municipalities (by groups of skill and origin).}

Since we are not able to distinguish migrants' origin, we cannot determine whether decision patterns differ between migrants' from different countries of origins. Nevertheless, our finding partially contradict Bartel (1989), who found that skilled migrants of certain origins to the US tend to relocate away from large concentration of migrants, while low-skilled migrants tend to remain in areas where there is a concentration of migrants. We find evidence that suggests that the tendency of migrants to concentrate in certain locations depends on their skill level, as well as on the existing concentration of migrants in each location.

Moreover, the WTP for concentration of migrants is not necessarily always highest among groups of foreigners. For instance, where the share of migrants is low (below approximately $15 \%-20 \%$ ) the willingness to pay for presence of migrants is higher among skilled natives compared with that of low skilled migrants.

Investigating the average and marginal willingness-to-pay for the rest of the examined urban attributes, we find several additional differences in valuation between the various groups (see Table 7). 
Table 7 - Marginal Willingness-to-pay for urban amenities (in Euro)

\begin{tabular}{|c|c|c|c|c|c|}
\hline & AWTP & $\begin{array}{l}\text { Native-Low } \\
\text { education }\end{array}$ & $\begin{array}{l}\text { Native - High } \\
\text { education }\end{array}$ & $\begin{array}{l}\text { Migrant - Low } \\
\text { education }\end{array}$ & $\begin{array}{l}\text { Migrants - High } \\
\text { education }\end{array}$ \\
\hline Jobs & 485.1 & 442.1 & 666.9 & 434.8 & 502.0 \\
\hline Monuments & 15.7 & 14.4 & 16.8 & 16.0 & 25.1 \\
\hline Nature & 735.8 & 719.1 & 661.5 & 870.7 & 686.1 \\
\hline Accessibility * & -808.3 & -480.2 & $-1,363.4$ & -404.8 & $-3,763.1$ \\
\hline LQ (ICT industries) * & 924.5 & 252.8 & 104.1 & $2,210.8$ & $6,103.7$ \\
\hline
\end{tabular}

Note: * Values are based on coefficients which are not statistically significant

While skilled domestic workers have a relatively high MWTP for jobs (667 EUR for an additional 1000 work places), the rest of the groups have a relatively similar MWTP values, around 430-500 Euros for an additional 1000 jobs. Although skilled migrants have a higher valuation for number of jobs (or urban scale), compared with both groups of low skilled workers, their MWTP is not sufficiently higher in order to conclude that there is a skill-bias in the valuation of this amenity. On the other hand, the valuation of natural and recreational amenities supports the assertion that a skill-bias exists in valuation pattern of urban amenities. Educated workers of both origin groups present similar MWTP for nature coverage (661 and 686 EUR for every additional square kilometer, for local and foreign workers respectively). This is while lower-educated workers show a much higher MWTP of 719 and 870 EUR for locals and migrants respectively.

The marginal willingness-to-pay for monuments or historic buildings presents a similar pattern. Consistently with the findings of Van Duijn and Rouwendal (2013), the highest values of MWTP are among highly-educated respondents. However, the gaps between the values are relatively large. The highest MWTP by a margin is among skilled migrants (25 EUR for every additional monument), while the second highest is 17 EUR among educated natives. Lower-educated native and migrants workers have a similar valuation of 14.4 and 16.0 respectively, values which are only slightly lower than that of the skilled natives' group. The results show that highly-educated households generally still have a higher MWTP for historic buildings compared with loweducated households, but mainly that skilled migrants have a clearly distinct preference for historic cities. Despite the fact that these WTP for monuments values appear relatively low at first sight, they are particularly high when reminded about the number of monuments in Dutch municipalities (described in appendix A.1). 21 municipalities in the sample have more than 200 monuments, and the municipalities of Utrecht, Leiden, Haarlem and Den-Haag all have over 1,000 monuments. This implies that the average household is willing to pay around 20,000 Euros to reside in one of these municipalities due to their provision of monuments and historical buildings alone. The WTP for monuments extremely increases when considering Amsterdam, which has 7,442 listed monuments - between 106 and 186 thousand Euros. Arguably, this high number seems particularly high compared to initial expectations. A possible explanation for this 
can be attributed to the indirect effects of cultural heritage. As mentioned before, monuments and historical centers are also correlated with other unobserved urban amenities, such as commercial and leisure consumption activities. These factors have an indirect contribution to the positive effect of monuments, and are reflected in the high willingness-to-pay values that are measured here. Given the number of monuments in the sample, the differences in WTP values between population groups are sharpened. For example, a skilled migrant is willing to pay approximately 36,000 Euro in order to reside in the city of Utrecht due to its 1,460 monuments. In contrast, a low skilled native is willing to pay 21,000 Euro for Utrecht's historical heritage, a difference of 15,000 Euro in valuation.

Average MWTP values of other labor related amenities, such as accessibility level and concentration of ICT industries, are harder to interpret due to the fact that they are based on statistically insignificant coefficients, and therefore the values are susceptible to bias. However, the statistically significant coefficients which were obtained in the first stage of the estimation still allow us to determine group-relative valuation of these amenities by examining deviations from the mean (see Table 8).

Table 8 - Marginal Willingness-to-pay for urban amenities (deviations from mean values in Euro)

\begin{tabular}{llllll} 
& AWTP & $\begin{array}{l}\text { Native-Low } \\
\text { education }\end{array}$ & $\begin{array}{l}\text { Native - High } \\
\text { education }\end{array}$ & $\begin{array}{l}\text { Migrant - Low } \\
\text { education }\end{array}$ & $\begin{array}{l}\text { Migrants - High } \\
\text { education }\end{array}$ \\
\hline Jobs & 484.2 & -43.0 & $181.8^{*}$ & $-50.3^{*}$ & 16.9 \\
Monuments & 15.7 & -1.4 & 1.1 & 0.3 & 9.4 \\
Nature & 735.9 & -16.8 & -74.3 & 134.8 & -49.7 \\
Accessibility & $-808.3^{*}$ & $328.2^{*}$ & -555.1 & $403.6 *$ & $-2,954.8$ \\
LQ (ICT industries) & $924.5^{*}$ & $-671.7^{*}$ & $-820.4^{*}$ & $1,286.3$ & $5,179.2$ \\
\hline
\end{tabular}

* Based on coefficients which are not statistically significant

The values in Table 8 show preference towards accessibility is strongest among skilled workers of both origin groups. Although it is particularly strong among educated migrants as they have the highest negative valuation by a large margin for an additional average kilometer distance from train station. Moreover, highly educated migrants also have a stronger willingness to pay for residing where a concentration of knowledge-intensive ICT industries exists. This is particularly interesting when compared to WTP of other groups - contrary to the expectations, educated natives have below average valuation of this amenity (statistically insignificant), while loweducated migrants have a positive valuation. This discrepancy can be partially explained by the fact the Location quotient measures were only available at a COROP area level (NUTS3), which may have resulted in a bias in the estimated values. 


\section{Discussion and conclusion}

The results of our estimation of the sorting model support the findings of previous researches, as we find evidence that residential location choices in Dutch municipalities depend much on the provision of urban amenities. Moreover, our results also provide further evidence that valuation patterns of urban amenities differ between individuals based on their household characteristics, particularly origin and skill level. We find that that job opportunities, as well as accessibility, natural amenities and particularly historical city centers, play a significant role in raising the attraction power of municipalities. Additionally, the role of social amenities, such as the share of migrants in a municipality, is also found to be an important explanatory variable. The implication is that cultural diversity and social interaction between inhabitants have a strong impact on households' location decisions, and on the attractiveness of municipalities, at least as much as other consumer or labor-related urban amenities. This positive effect on municipality attractiveness is found to be even stronger in municipalities neighboring large communities of migrants, as reflected by the higher value of the spatially-lagged variable's coefficient. Consistent with findings of previous researches, our results also show that both positive and negative effects may result from an existent community of migrants. We observe this as the MWTP for an additional share of migrants in a municipality changes with the share of migrants in the municipalities- it is found to be high among all skill and origin groups where migrants shares are low, but decreases where the shares and presence of foreigners is relatively high.

We also find that with respect to most urban amenities, the location preferences of skilled migrants are generally more similar to those of the highly-educated natives rather than to lowskilled migrants, assuming that other household characteristics are identical. This is visible in MWTP values of both work-related amenities, such as the number of jobs or accessibility, but also in preferences for other urban amenities, such as historical buildings and nature. In this sense, and also somewhat expectedly, preference for an existing community of migrants forms an exception in the skill-based pattern of preference for urban amenities. Skilled migrants are found to be more similar to low skilled migrants in their preferences for shares of migrants in a municipality. Their MWTP values for an existing community of migrants even exceed those of the low-skilled migrants, assuming all other characteristics are identical. This may be explained as migrants of all skill levels are assumed to derive utility from cultural goods, but skilled migrants may also enjoy the network benefits of a large community of migrants, which may increase their expected labor outcomes. Furthermore, our results point out that highly-educated migrants have the highest MWTP among all groups for historic city centers and buildings. This valuation becomes considerably significant in municipalities that are rich in historical districts.

These findings may be useful for urban policy that aims to attract foreign educated workers. First, municipalities can attract skilled and highly-educated foreign workers by preserving their historic 
districts, and developing them in order to maintain their historic and leisurely value. Moreover, since the share of migrants is also found to be an important factor for location decisions, urban policy can be aimed to stress the positive effects and minimize the possible negative effects which may result from it. Although an existing community of migrants is not an amenity which can be developed artificially as part of an urban policy, municipalities can still aim to preserve the positive effects from an existing community. One possible example of such policy may be encouraging language proficiency courses, which may reduce communication barriers.

Our research's findings contribute to the literature by identifying housing preferences and valuation of urban amenities of skilled and migrant workers based on their individual characteristics. We addressed challenges such as model endogeneity, spatial dependence and omitted variable bias by estimating a two-step residential sorting model and by instrumenting for housing prices and the existing share of migrants. We find that social interaction and labor market amenities are important determinants of location decisions, and that the location preferences of skilled migrants show more similarities to those of skilled native workers. If data availability permits, further research on the valuation of urban amenities by population groups should also focus on the country of origin composition of the group of migrants. This will be useful in identification of individual characteristics, and would allow including the level of cultural diversity within municipalities into the model by using a diversity measure.

\section{References}

Adamson, D. W., Clark, D. E., \& Partridge, M. D. (2004). Do Urban Agglomeration Effects and Household Amenities have a Skill Bias?*. Journal of Regional Science, 44(2), 201-224.

Anselin, L. (1988). Spatial Econometrics: Methods and Models. Operational Regional Science Series (p. 289).

Anselin, L., Bera, A., Florax, R., \& Yoon, M. (1996). Simple diagnostic tests for spatial dependence. Regional Science and Urban Economics, 26(1), 77-104.

Åslund, O. (2005). Now and forever? Initial and subsequent location choices of immigrants. Regional Science and Urban Economics, 35(2), 141-165.

Bartel, a P. (1989). Where do the new U.S. immigrants live? Journal of Labor Economics, 7(4), 371-91.

Bauer, T., Epstein, G. S., Gang, I. N., \& Al, E. T. (2007). The Influence Of Stocks and Flows On Migrants’ Location Choices. Research in Labor Economics, 26(06), 199-229. 
Bayer, P., Ferreira, F., \& Mcmillan, R. (2007). A Unified Framework for Measuring Preferences for Schools and Neighborhoods. Journal of Political Economy, 115(4), 588-638.

Bayer, P., Mcmillan, R., \& Rueben, K. (2004). An equilibrium sorting model of sorting in an urban housing market (No. w10865). NBER.

Bellini, E., Ottaviano, G., Pinelli, D., \& Prarolo, G. (2008). Cultural diversity and economic performance: evidence from European regions. Hamburg Institute of International Economics (HWWI), (3-14).

Berndt, C. A. E. K., Hall, B. H., Hall, R. E., \& Hausman, J. A. (1974). Estimation and Inference in Nonlinear Structural Models. Annals of Economic and Social Measurement, 3(4), 653665.

Berry, S., Levinsohn, J., Pakes, A., \& Berry, B. Y. S. (1995). Automobile Prices in Market Equilibrium. Econometrica, 63(4), 841-890.

Borjas, G. J. (1994). Ethnicity, neighborhoods, and human capital externalities. NBER, (No. w4912).

Brown, W. M., \& Scott, D. M. (2012). Human Capital Location Choice: Accounting for Amenities and Thick Labor Markets. Journal of Regional Science, 52(5), 787-808.

Brueckner, J. (2000). Urban sprawl: diagnosis and remedies. International Regional Science ..., 23(2), 160-171.

Damm, A. P. (2012). Neighborhood Quality and Labor Market Outcomes: Evidence from QuasiRandom Neighborhood Assignment of Immigrants. CReAM Discussion Paper, (35).

Drukker, D. M., Egger, P., \& Prucha, I. R. (2013). On Two-Step Estimation of a Spatial Autoregressive Model with Autoregressive Disturbances and Endogenous Regressors. Econometric Reviews, 32(5-6), 686-733.

Drukker, D. M., \& Prucha, I. R. (2011). A command for estimating spatial-autoregressive models with spatial-autoregressive disturbances and additional endogenous variables. The Stata Journal, (1), 1-13.

Eeckhout, J., Pinheiro, R., \& Schmidheiny, K. (2010). Spatial sorting: Why New York, Los Angeles and Detroit attract the greatest minds as well as the unskilled (No. 3274).

Glaeser, E., Kolko, J., \& Saiz, A. (2001). Consumer city. Journal of Economic Geography, 1(1), $27-50$.

Glaeser, E., \& Resseger, M. G. (2010). the Complementarity Between Cities and Skills. Journal of Regional Science, 50(1), 221-244. 
Glaeser, E., \& Saiz, A. (2003). The rise of the skilled city (No. w10191). Harvard Institute of Economic Research (HIER).

Goldin, C., \& Katz, L. (2009). The race between education and technology (Vol. 12984).

Gottlieb, P. D., \& Joseph, G. (2006). College-To-Work Migration of Technology Graduates and Holders of Doctorates Within the United States. Journal of Regional Science, 46(4), 627659.

Hunt, J., \& Gauthier-Loiselle, M. (2008). How much does immigration boost innovation? (No. w14312).

Jaeger, D. A. (2006). Green Cards and the Location Choices of Immigrants in the United States, 1971-2000. Institute for the Study of Labor (IZA), (IZA Discussion Papers, No. 2145).

Klaiber, H. A., \& Phaneuf, D. J. (2010). Valuing Open Space in a Residential Sorting Model of the Twin Cities. Journal of Environmental Economics and Management, 60(2), 57-77.

McFadden, D., \& Train, K. (2000). Mixed MNL Models For Discrete Response. Journal of Applied Econometrics, 15(5), 447-470.

Mocetti, S., \& Porello, C. (2010). How does immigration affect native internal mobility? New evidence from Italy. Regional Science and Urban Economics, 40(6), 427-439.

Moretti, E. (2004). Human capital externalities in cities. Handbook of Regional and Urban Economics, 4, 2243-2291.

Moretti, E. (2010). Local Multipliers. American Economic Review, 100(2), 373-377.

Moretti, E. (2012). The New Geography of Jobs. Journal of Economic Geography. Houghton Mifflin Harcourt.

Moretti, E., \& Thulin, P. (2013). Local multipliers and human capital in the United States and Sweden. Industrial and Corporate Change, 22(1), 339-362.

Munshi, K. (2003). Networks in the modern economy: mexican migrants in the u. s. labor market. Quarterly Journal of Economics, (May), 549-598.

Niebuhr, A. (2010). Migration and innovation: Does cultural diversity matter for regional R\&D activity? Papers in Regional Science, 89(3), 563-585.

Ottaviano, G., \& Peri, G. (2006). The economic value of cultural diversity: evidence from US cities. Journal of Economic Geography, 6(1), 9-44.

Ozgen, C., Nijkamp, P., \& Poot, J. (2011). Immigration and Innovation in European Regions (No. 5676). 
Rodríguez-Pose, A., \& Ketterer, T. D. (2012). Do Local Amenities Affect the Appeal of Regions in Europe for Migrants?*. Journal of Regional Science, 52(4), 535-561.

Suedekum, J., Wolf, K., \& Blien, U. (2009). Cultural diversity and local labour markets (No. 4619). Regional Studies.

Van Duijn, M., \& Rouwendal, J. (2013). Cultural heritage and the location choice of Dutch households in a residential sorting model. Journal of Economic Geography, 13(3), 473-500.

Appendix A.1 : Randstad Municipalities: Full characteristics table (Source: CBS, NVM, RCE)

\begin{tabular}{|c|c|c|c|c|c|c|c|c|c|}
\hline$\#$ & Municipality & $\begin{array}{c}\text { COROP } \\
\text { area } \\
(\text { NUTS3)* }\end{array}$ & $\begin{array}{c}\text { Housing } \\
\text { prices }\end{array}$ & P.migrants & $\begin{array}{c}\text { Accessibility } \\
\text { (av. Dist to } \\
\text { train } \\
\text { station) }\end{array}$ & Jobs & Monuments & Nature & $\begin{array}{c}\text { LQ (ICT } \\
\text { industries) }\end{array}$ \\
\hline 1 & 's-Gravenhage & 1 & 200,282 & 47.3 & 3 & 268.86 & 1154 & 11.7 & 3.47 \\
\hline 2 & Aalsmeer & 4 & 239,541 & 14.6 & 8.1 & 16.82 & 36 & 3.4 & 1.79 \\
\hline 3 & Alblasserdam & 10 & 193,780 & 12.7 & 9.8 & 8.42 & 22 & 2.1 & 0.48 \\
\hline 4 & Albrandswaard & 11 & 201,689 & 16.1 & 8.7 & 7.95 & 29 & 10.4 & 0.45 \\
\hline 5 & Almere & 6 & 162,833 & 36.4 & 1.8 & 67.23 & 4 & 24 & 0.93 \\
\hline 6 & Alphen aan den Rijn & 7 & 211,606 & 19.8 & 2.6 & 32.89 & 74 & 0.1 & 0.93 \\
\hline 7 & Amersfoort & 3 & 219,143 & 22.4 & 2.4 & 85.5 & 424 & 7.8 & 2.1 \\
\hline 8 & Amstelveen & 4 & 283,645 & 32.8 & 6.2 & 43.39 & 44 & 9.3 & 1.79 \\
\hline 9 & Amsterdam & 4 & 312,538 & 49.5 & 2.5 & 513.18 & 7442 & 2.2 & 1.79 \\
\hline 10 & Baarn & 3 & 263,941 & 15.5 & 1.5 & 11.81 & 151 & 50.7 & 2.1 \\
\hline 11 & Barendrecht & 11 & 201,890 & 18.6 & 3.1 & 21.52 & 20 & 2.9 & 0.45 \\
\hline 12 & Beemster & 4 & 223,123 & 8.2 & 6.5 & 3.04 & 90 & 0.2 & 1.79 \\
\hline 13 & Bergambacht & 7 & 216,746 & 7.1 & 12.5 & 3.68 & 33 & 1.5 & 0.93 \\
\hline 14 & Bernisse & 11 & 193,200 & 8 & 16.4 & 2.6 & 95 & 1.4 & 0.45 \\
\hline 15 & Beverwijk & 13 & 187,115 & 21.4 & 1.7 & 20.72 & 35 & 11.7 & 0.22 \\
\hline 16 & Binnenmaas & 11 & 199,482 & 8.1 & 9.9 & 7.25 & 73 & 2.5 & 0.45 \\
\hline 17 & Blaricum & 2 & 321,091 & 16.5 & 7.6 & 1.87 & 69 & 22.4 & 2.43 \\
\hline 18 & Bloemendaal & 5 & 366,400 & 17 & 1.8 & 4.16 & 237 & 66 & 1.44 \\
\hline 19 & Bodegraven & 7 & 219,362 & 11.9 & 1.5 & 8.94 & 27 & 0.6 & 0.93 \\
\hline 20 & Boskoop & 7 & 210,972 & 13.3 & 1.9 & 4.01 & 12 & 0.1 & 0.93 \\
\hline 21 & Brielle & 11 & 214,160 & 11.6 & 11.6 & 4.73 & 374 & 2 & 0.45 \\
\hline 22 & Bunnik & 3 & 255,884 & 10.9 & 2.5 & 7.05 & 56 & 4.7 & 2.1 \\
\hline 23 & Bunschoten & 3 & 214,160 & 7.1 & 8.9 & 9.81 & 14 & 0.4 & 2.1 \\
\hline 24 & Bussum & 2 & 268,466 & 19.4 & 1.4 & 11.9 & 49 & 12.5 & 2.43 \\
\hline 25 & Capelle aan den IJssel & 11 & 199,285 & 29.5 & 3.2 & 45.54 & 17 & 0.4 & 0.45 \\
\hline 26 & Castricum & 13 & 237,395 & 9.6 & 2.5 & 8.8 & 48 & 28.3 & 0.22 \\
\hline 27 & Cromstrijen & 11 & 196,120 & 6.4 & 18.6 & 4.05 & 14 & 2.1 & 0.45 \\
\hline 28 & De Bilt & 3 & 270,622 & 14.9 & 2.4 & 15.88 & 160 & 23.4 & 2.1 \\
\hline 29 & De Ronde Venen & 3 & 248,570 & 12.6 & 10.6 & 11.86 & 35 & 0.3 & 2.1 \\
\hline 30 & Delft & 8 & 230,609 & 29.7 & 1.5 & 52.49 & 689 & 4.9 & 0.65 \\
\hline 31 & Diemen & 4 & 255,118 & 37 & 1.1 & 33.32 & 16 & 22.7 & 1.79 \\
\hline 32 & Dirksland & 11 & 171,182 & 3.9 & 34.1 & 2.78 & 31 & 18.9 & 0.45 \\
\hline 33 & Dordrecht & 10 & 179,240 & 27.2 & 1.7 & 57.43 & 891 & 14 & 0.48 \\
\hline 34 & Edam-Volendam & 4 & 239,541 & 7 & 9 & 11.11 & 179 & 0 & 1.79 \\
\hline 35 & Eemnes & 3 & 253,338 & 12.2 & 6.8 & 2.09 & 43 & 3.3 & 2.1 \\
\hline 36 & Giessenlanden & 10 & 218,050 & 5.7 & 4.1 & 3.81 & 65 & 0.6 & 0.48 \\
\hline 37 & Goedereede & 11 & 213,092 & 4 & 29.2 & 4.21 & 137 & 34.5 & 0.45 \\
\hline 38 & Gorinchem & 10 & 204,532 & 23.3 & 1.8 & 23.77 & 218 & 1.9 & 0.48 \\
\hline 39 & Gouda & 7 & 198,091 & 22.1 & 1.6 & 37.74 & 354 & 0.9 & 0.93 \\
\hline 40 & Graafstroom & 10 & 190,133 & 3.6 & 7.5 & 3.5 & 91 & 1.7 & 0.48 \\
\hline
\end{tabular}




\begin{tabular}{|c|c|c|c|c|c|c|c|c|c|}
\hline 41 & Graft-De Rijp & 4 & 198,289 & 7.2 & 11.2 & 1.47 & 137 & 1.9 & 1.79 \\
\hline 42 & Haarlem & 5 & 251,319 & 24.5 & 2 & 70.58 & 1182 & 1.4 & 1.44 \\
\hline 43 & $\begin{array}{l}\text { Haarlemmerliede en } \\
\text { Spaarnwoude }\end{array}$ & 5 & 238,346 & 12.3 & 5.2 & 1.4 & 16 & 13.4 & 1.44 \\
\hline 44 & Haarlemmermeer & 4 & 225,819 & 22.3 & 4.3 & 149.43 & 20 & 0.5 & 1.79 \\
\hline 45 & Hardinxveld-Giessendam & 10 & 211,396 & 4.6 & 2 & 8.42 & 11 & 3.5 & 0.48 \\
\hline 46 & Heemskerk & 13 & 208,664 & 17.5 & 2.9 & 8.17 & 22 & 38.4 & 0.22 \\
\hline 47 & Heemstede & 5 & 328,890 & 17.2 & 2.3 & 7.6 & 97 & 15.1 & 1.44 \\
\hline 48 & Hellevoetsluis & 11 & 183,045 & 16.7 & 16.8 & 9.93 & 52 & 6 & 0.45 \\
\hline 49 & Hendrik-Ido-Ambacht & 10 & 201,487 & 11.6 & 4.1 & 7.37 & 9 & 1.1 & 0.48 \\
\hline 50 & Hillegom & 9 & 226,495 & 13.9 & 2.7 & 7.2 & 7 & 1.5 & 0.55 \\
\hline 51 & Hilversum & 2 & 242,433 & 22 & 1.6 & 53.81 & 211 & 42.5 & 2.43 \\
\hline 52 & Houten & 3 & 219,582 & 12.9 & 2.2 & 19.84 & 134 & 1.3 & 2.1 \\
\hline 53 & Huizen & 2 & 260,532 & 18.6 & 7.5 & 12.86 & 39 & 29.3 & 2.43 \\
\hline 54 & IJsselstein & 3 & 204,532 & 19.1 & 11.3 & 11.26 & 68 & 1.5 & 2.1 \\
\hline 55 & Kaag En Braassem & 9 & 311,001 & 7.1 & 7.7 & 6.88 & 60 & 0 & 0.55 \\
\hline 56 & Katwijk & 9 & 251,319 & 8.5 & 6.5 & 24.62 & 51 & 17.4 & 0.55 \\
\hline 57 & Korendijk & 11 & 196,316 & 5.5 & 22.8 & 1.77 & 46 & 6 & 0.45 \\
\hline 58 & Krimpen aan den IJssel & 11 & 215,665 & 12.3 & 7.4 & 8.8 & 14 & 2.9 & 0.45 \\
\hline 59 & Landsmeer & 4 & 267,930 & 12.5 & 8 & 1.91 & 7 & 12.8 & 1.79 \\
\hline 60 & Lansingerland & 11 & 216,313 & 13.7 & 6.7 & 18.57 & 17 & 3 & 0.45 \\
\hline 61 & Laren & 2 & 361,667 & 20.9 & 5.1 & 5.48 & 98 & 50.3 & 2.43 \\
\hline 62 & Leerdam & 10 & 204,737 & 21 & 1.6 & 8.75 & 54 & 3.5 & 0.48 \\
\hline 63 & Leiden & 9 & 251,571 & 27.2 & 1.5 & 67.88 & 1243 & 1 & 0.55 \\
\hline 64 & Leiderdorp & 9 & 244,136 & 19 & 3.8 & 10.01 & 32 & 1.4 & 0.55 \\
\hline 65 & Leidschendam-Voorburg & 1 & 220,903 & 26.9 & 2.2 & 28.53 & 113 & 4.1 & 3.47 \\
\hline 66 & Leusden & 3 & 230,840 & 12.8 & 6.1 & 14.22 & 53 & 34.2 & 2.1 \\
\hline 67 & Liesveld & 10 & 211,817 & 4.9 & 13.4 & 4.37 & 90 & 1.9 & 0.48 \\
\hline 68 & Lisse & 9 & 231,765 & 11.5 & 6.8 & 9.8 & 41 & 9.4 & 0.55 \\
\hline 69 & Lopik & 3 & 208,457 & 6.4 & 15 & 4.2 & 127 & 2.1 & 2.1 \\
\hline 70 & Maassluis & 11 & 215,019 & 23.3 & 1.3 & 7.53 & 41 & 3.2 & 0.45 \\
\hline 71 & Middelharnis & 11 & 190,895 & 5.4 & 37.1 & 7.4 & 159 & 1.7 & 0.45 \\
\hline 72 & Midden-Delfland & 8 & 254,353 & 8.2 & 3.4 & 5.53 & 99 & 1.8 & 0.65 \\
\hline 73 & Montfoort & 3 & 227,176 & 8.2 & 6.8 & 4.85 & 98 & 1.6 & 2.1 \\
\hline 74 & Muiden & 2 & 276,642 & 15.7 & 5.2 & 1.54 & 75 & 7.9 & 2.43 \\
\hline 75 & Naarden & 2 & 296,998 & 18.4 & 2 & 10.67 & 163 & 29.3 & 2.43 \\
\hline 76 & Nederlek & 11 & 207,208 & 7.7 & 11.6 & 3.92 & 24 & 5.8 & 0.45 \\
\hline 77 & Nieuw-Lekkerland & 10 & 200,883 & 5.9 & 12.8 & 2.2 & 26 & 10 & 0.48 \\
\hline 78 & Nieuwegein & 3 & 206,175 & 22.4 & 7.5 & 51.22 & 80 & 3.3 & 2.1 \\
\hline 79 & Nieuwkoop & 7 & 227,403 & 7.8 & 10.3 & 7.89 & 27 & 7.6 & 0.93 \\
\hline 80 & Noordwijk & 9 & 278,307 & 14.8 & 5 & 11.35 & 74 & 52.6 & 0.55 \\
\hline 81 & Noordwijkerhout & 9 & 238,823 & 12 & 5.5 & 6.48 & 12 & 8.3 & $\overline{0.55}$ \\
\hline 82 & Oegstgeest & 9 & 275,813 & 21.4 & 3.1 & 6.34 & 44 & 3.7 & 0.55 \\
\hline 83 & Oostflakkee & 11 & 156,136 & 5.1 & 31 & 2.02 & 28 & 7 & 0.45 \\
\hline 84 & Oostzaan & 4 & 251,071 & 10.8 & 5.4 & 2.67 & 7 & 11 & 1.79 \\
\hline 85 & Oud-Beijerland & 11 & 212,879 & 9.2 & 14.9 & 12.13 & 28 & 0.5 & 0.45 \\
\hline 86 & Ouder-Amstel & 4 & 287,932 & 20.2 & 3.2 & 9.3 & 36 & 0.9 & 1.79 \\
\hline 87 & Ouderkerk & 11 & 206,381 & 6 & 8.9 & 2.62 & 38 & 1.1 & 0.45 \\
\hline 88 & Oudewater & 3 & 245,605 & 6.3 & 9.4 & 3.1 & 159 & 0.1 & 2.1 \\
\hline 89 & Papendrecht & 10 & 197,300 & 15 & 6.5 & 11.94 & 2 & 4.1 & 0.48 \\
\hline 90 & Pijnacker-Nootdorp & 1 & 224,244 & 15.5 & 4 & 12.21 & 22 & 7.3 & 3.47 \\
\hline 91 & Purmerend & 4 & 196,709 & 23.2 & 1.9 & 26.44 & 30 & 12.1 & 1.79 \\
\hline 92 & Renswoude & 3 & 224,915 & 4.6 & 4.6 & 1.82 & 34 & 5.5 & 2.1 \\
\hline 93 & Rhenen & 3 & 216,963 & 9.7 & 2.6 & 5.03 & 53 & 32.9 & 2.1 \\
\hline 94 & Ridderkerk & 11 & 200,482 & 14.4 & 5.6 & 20.87 & 57 & 2.1 & 0.45 \\
\hline 95 & Rijnwoude & 7 & 218,705 & 7.8 & 5.8 & 6.53 & 81 & 0.7 & 0.93 \\
\hline 96 & Rijswijk & 1 & 197,300 & 27.8 & 1.8 & 35.24 & 76 & 0.4 & 3.47 \\
\hline 97 & Rotterdam & 11 & 182,313 & 46.9 & 2.8 & 370.03 & 466 & 2.9 & 0.45 \\
\hline 98 & Schiedam & 11 & 164,141 & 33.5 & 1.7 & 35.26 & 238 & 1.7 & 0.45 \\
\hline 99 & Schoonhoven & 7 & 217,832 & 15 & 12.9 & 4.82 & 148 & 1.2 & 0.93 \\
\hline 100 & Sliedrecht & 10 & 205,147 & 11.3 & 1.9 & 13.57 & 8 & 0.6 & 0.48 \\
\hline 101 & Soest & 3 & 243,161 & 19.1 & 2.2 & 19.83 & 43 & 38.3 & 2.1 \\
\hline
\end{tabular}




\begin{tabular}{|c|c|c|c|c|c|c|c|c|c|}
\hline 102 & Spijkenisse & 11 & 172,384 & 22.7 & 13.7 & 21.36 & 5 & 5.2 & 0.45 \\
\hline 103 & Stichtse Vecht & 3 & 248,570 & 11.9 & 2.9 & 6 & 196 & 1.5 & 2.1 \\
\hline 104 & Strijen & 11 & 211,183 & 7.5 & 13.3 & 2.23 & 14 & 3.5 & 0.45 \\
\hline 105 & Teylingen & 9 & 245,851 & 12.7 & 2.7 & 12.53 & 107 & 2.3 & 0.55 \\
\hline 106 & Uitgeest & 13 & 204,123 & 10.3 & 1.5 & 3.76 & 20 & 1.7 & 0.22 \\
\hline 107 & Uithoorn & 4 & 228,086 & 18.4 & 11.5 & 12.56 & 12 & 0.4 & 1.79 \\
\hline 108 & Utrecht & 3 & 250,316 & 31.5 & 1.9 & 229.85 & 1459 & 2 & 2.1 \\
\hline 109 & Utrechtse Heuvelrug & 3 & 259,232 & 13.5 & 4.4 & 20.98 & 421 & 45 & 2.1 \\
\hline 110 & Veenendaal & 3 & 217,397 & 15.8 & 1.4 & 30.25 & 16 & 3.4 & 2.1 \\
\hline 111 & Velsen & 13 & 227,858 & 15.2 & 2.5 & 31.46 & 138 & 27.6 & 0.22 \\
\hline 112 & Vianen & 3 & 205,557 & 14.3 & 10.4 & 12.07 & 181 & 8.1 & 2.1 \\
\hline 113 & Vlaardingen & 11 & 184,514 & 24.4 & 1.9 & 23.3 & 56 & 11 & 0.45 \\
\hline 114 & Vlist & 7 & 231,997 & 5.7 & 6.1 & 3.14 & 91 & 0.1 & 0.93 \\
\hline 115 & Voorschoten & 9 & 263,413 & 20.5 & 1.5 & 5 & 103 & 6.4 & 0.55 \\
\hline 116 & Waddinxveen & 7 & 208,875 & 12.8 & 1.2 & 12.14 & 6 & 0.9 & 0.93 \\
\hline 117 & Wassenaar & 1 & 329,220 & 29.8 & 3.9 & 7.49 & 272 & 49.3 & 3.47 \\
\hline 118 & Waterland & 4 & 254,353 & 10.3 & 10.3 & 3.15 & 317 & 2.3 & 1.79 \\
\hline 119 & Weesp & 2 & 260,532 & 23.7 & 1.3 & 10.25 & 221 & 0.5 & 2.43 \\
\hline 120 & Westland & 8 & 230,840 & 9.5 & 6.5 & 57.14 & 76 & 4.8 & 0.65 \\
\hline 121 & Westvoorne & 11 & 246,836 & 9.1 & 17.6 & 3.62 & 29 & 28.3 & 0.45 \\
\hline 122 & Wijdemeren & 2 & 282,513 & 11.4 & 6 & 6.34 & 249 & 14.7 & 2.43 \\
\hline 123 & Wijk bij Duurstede & 3 & 233,160 & 10.5 & 10.5 & 5.09 & 166 & 8.5 & 2.1 \\
\hline 124 & Woerden & 3 & 230,379 & 12.5 & 2.9 & 25.58 & 103 & 0.7 & 2.1 \\
\hline 125 & Wormerland & 12 & 207,831 & 11 & 2.5 & 4.09 & 33 & 1.1 & 0.25 \\
\hline 126 & Woudenberg & 3 & 240,021 & 7.7 & 5 & 4.05 & 30 & 24.5 & 2.1 \\
\hline 127 & Zaanstad & 12 & 192,621 & 25.7 & 2.1 & 56.62 & 258 & 5.6 & 0.25 \\
\hline 128 & Zandvoort & 5 & 277,473 & 18.7 & 1 & 4.66 & 11 & 77.9 & 1.44 \\
\hline 129 & Zederik & 10 & 220,024 & 4 & 8.4 & 4.47 & 106 & 3.6 & 0.48 \\
\hline 130 & Zeevang & 4 & 205,969 & 9.5 & 8.2 & 1.25 & 23 & 1 & 1.79 \\
\hline 131 & Zeist & 3 & 264,999 & 21.4 & 3.9 & 36.21 & 155 & 44.9 & 2.1 \\
\hline 132 & Zoetermeer & 1 & 200,482 & 27.7 & 3.5 & 48.9 & 16 & 1.3 & 3.47 \\
\hline 133 & Zoeterwoude & 9 & 245,605 & 9.3 & 4 & 7 & 40 & 0.7 & 0.55 \\
\hline 134 & Zuidplas & 11 & 210,130 & 13.2 & 1.2 & 6.5 & 14 & 4.8 & 0.45 \\
\hline 135 & Zwijndrecht & 10 & 192,236 & 18.4 & 2.3 & 19.52 & 13 & 1.5 & 0.48 \\
\hline
\end{tabular}




\begin{tabular}{|lc|}
\hline *COROP area (NUTS3) & Number \\
\hline Agglomeratie S-Gravenhage & 1 \\
Het Gooi En Vechtstreek & 2 \\
Utrecht & 3 \\
Groot-Amsterdam & 4 \\
Agglomeratie Haarlem & 5 \\
Flevoland & 6 \\
Oost-Zuid-Holland & 7 \\
Delft En Westland & 8 \\
Agglomeratie Leiden En Bollenstreek & 9 \\
Zuidoost-Zuid-Holland & 10 \\
Groot-Rijnmond & 11 \\
Zaanstreek & 12 \\
Ijmond & 13 \\
\hline
\end{tabular}

Appendix B.1: Map of Randstad municipalities alternative specific constants

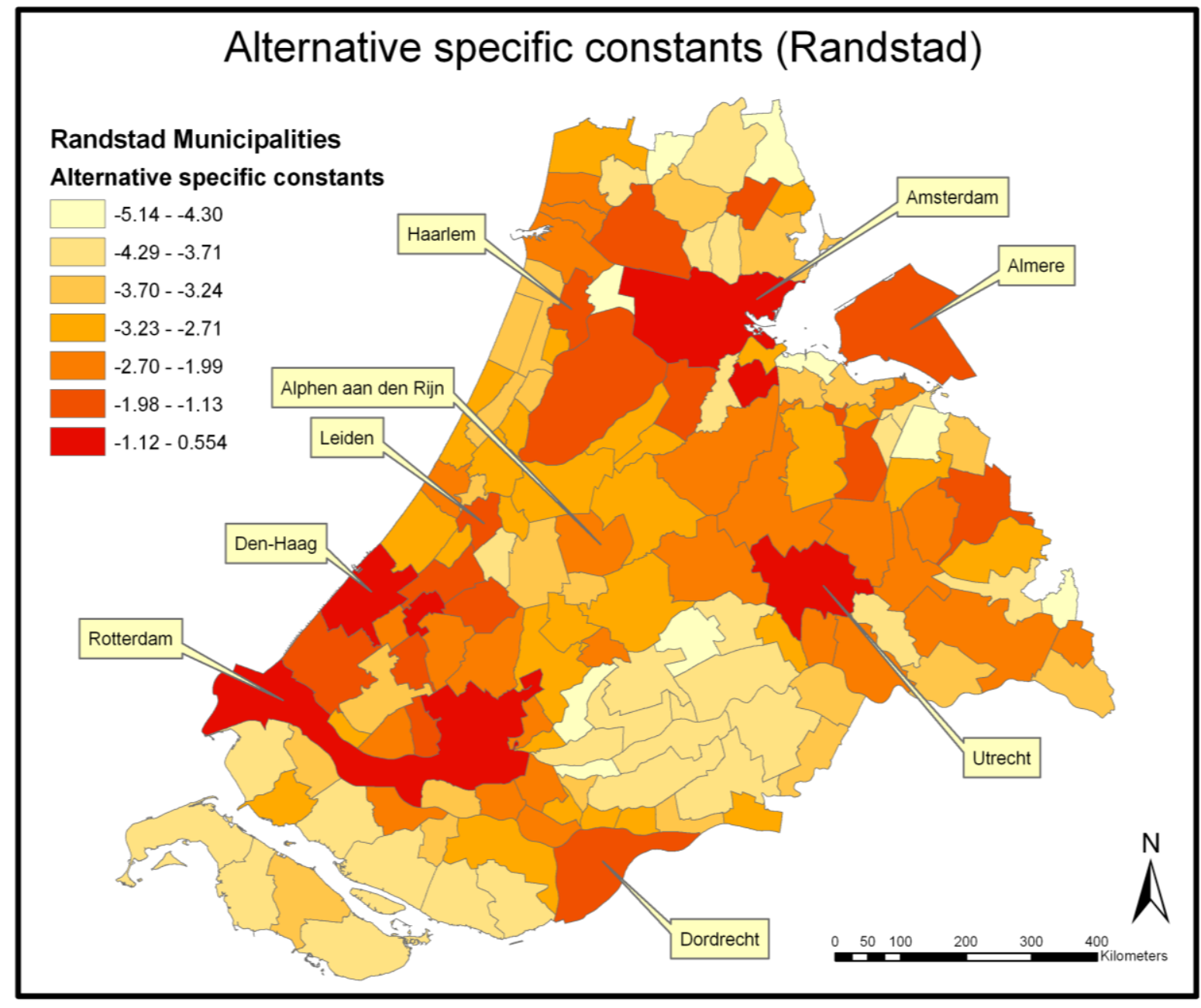

